\title{
EXPERIMENTAL RESEARCH OF OIL EXTRACTION FROM CANOLA BY USING MICROWAVE TECHNOLOGY
}

\author{
Oleg Burdo ${ }^{1}$, Valentyna Bandura ${ }^{2}$, Ludmyla Kolianovska ${ }^{2}$, Ilmars Dukulis ${ }^{3}$ \\ ${ }^{1}$ Odessa National Academy of Food Technologies, Ukraine; \\ ${ }^{2}$ Vinnytsia National Agrarian University, Ukraine; ${ }^{3}$ Latvia University of Agriculture, Latvia \\ semjons@apollo.lv
}

\begin{abstract}
One of the most important stages of the technological process of extraction of target components from the seeds of the agricultural oil crops by the extraction method is extraction which lasts for the longest time, and therefore it actually determines, on the whole, the speed and economic efficiency of the entire process. The aim of the work was to study the extraction kinetics canola (rapeseed) (oilcake and whole grain) to determine the optimal technological parameters (kind of the extragent, hydromodule, value of the function) of the process carried out in a microwave field. As a result of the investigations of the concentration of the obtained oil, it was found that, in contrast to alcohol, the solvent hexane ensures a higher intensity of the process, a greater diffusion and solubility coefficient. However, the experimental research of the intensity of action of the solvents under the impact of the microwave field, and without it (at the temperature conditions of boiling solvents), showed that intensified action of ethyl alcohol (ethanol) during the extraction in a microwave field is 1.5 times more intensive than the action of hexane. The conducted investigations indicate that, in case oil is extracted from canola (rapeseed) under microwave field conditions, preference should be given to a polar, nontoxic and more safe (in contrast to hexane) solvent - ethyl alcohol (ethanol).
\end{abstract}

Keywords: canola (rapeseed), extraction, hexane, ethyl alcohol (ethanol), temperature, microwaves.

\section{Introduction}

At present in most countries of Northern and Eastern Europe, the areas under canola (rapeseed) are constantly growing and occupy a significant place in the structure of crops. Canola is the most important source of vegetable oil for the food industry, biofuel production, and other technical purposes. Seeds of rape contain: oils $-40 \ldots 45 \%$, raw protein $-18 \ldots 22 \%$ (proteins are well balanced by amino acid composition, $5 \%$ of the total number of amino acids account for the proportion of sulfur-containing amino acids), cellular tissue $-6 \ldots 7 \%$, phospholipids $0.2 \ldots 1.2 \%$, which are characterized by an increased content of non-hydratable forms. Besides, the canola seeds contain natural antioxidants - tocopherols (vitamin E), phenolic compounds and tannins $[1 ; 2]$.

Extraction method of production of vegetable oils is the main one in the fat and oil industry and its improvement determines the efficiency of the industry. In the process of extracting oil from the crushed raw material, a miscella (an oil solution in a solvent) and a defatted residue (meal) are obtained. For the extraction of oil, the solvent is subsequently evaporated from the miscella. Traditional processes of extracting biologically active compounds from the plant raw materials have two main drawbacks: considerable duration and incomplete recovery of the target products. Extraction processes in modern food technologies for the production of oils are crucial, determining both the quality and economic indicators of the enterprise. Therefore, the intensification of the processing of the canola raw materials for the purpose of more complete and rapid extraction of valuable substances is a promising and urgent task.

The composition of all cells of the plant raw material includes the cytoplasm, which is limited to a plasma (cell) membrane with a thickness of 7.5 to $15 \mathrm{~nm}$ [3]. In the membrane there are pores with a diameter of $0.35 \ldots 0.8 \mathrm{~nm}$, due to which it has filtration and ion exchange capabilities.

The total mass transfer resistance during the extraction from the plant material consists of the sum of internal resistance within the cell at the boundary of the semiconductor septum; the resistance of the diffuse layer, the thickness of which depends on the viscous abilities of the solutions of substances diffusing through the cell membrane and the hydrodynamic conditions of the medium; the convective resistance, is limited by factors of external influence on the medium (mixing, heating, frequency oscillations) $[4 ; 5]$.

The basis for the use of microwaves with frequencies from $300 \mathrm{MHz}$ to $30 \mathrm{GHz}$ in the food industry is their property of heating products. The positive qualities of microwave heating in contrast to the traditional methods of processing products is: high process speed (so, the drying time is reduced by $10 \ldots 30$ times), a short time to enter the mode (does not exceed $1 \ldots 2 \mathrm{~min}$ ), the material warms up 
simultaneously (the heat is distributed through entire volume of the material, regardless of its thermal conductivity), the selectivity of the process: the wet parts of the material warm up faster than the dry parts, which is not peculiar to the convection heating, the lack of inertness of heating and the possibility of complete automation of the process (heating can be quickly started and also quickly stopped), and many other advantages [7].

To the shortcomings that limit the use of microwave technologies in the extraction of plant raw materials belong [7]: a high initial cost, insufficiently high operating life of the microwave generators (10.15 thousand hours), the part of the cost of generators in the total price of the installation being about $50 \%$, lack of sufficient cheap containers of dielectric materials with high temperature stability, the lack of a sufficient amount of reliable material about the dielectric characteristics of food products and their ability to absorb when absorbing electromagnetic energy, the lack of sufficient material for the economic justification of the efficiency and evaluation of engineering in microwave technologies, and many other factors.

The use of the principles of nanotechnologies, technologies of directional energy action makes it possible to substantially intensify the extraction process due to the effect of combined electrophysical impact by a pulsed electromagnetic field [8-11].

\section{Materials and methods}

The aim of this work is experimental research and determination of the parameters of microwave treatment in which the greatest yield of the target components takes place.

Studies on the extraction kinetics were carried out with the canola sort "Ozimyi" (cake and whole grain) by determining the effect on the process of the following process parameters: size of raw material fractions $(d, \mathrm{~mm})$, presence and magnitude of the power $(N, \mathrm{~W})$ of the pulsed electromagnetic field (IEM Field), hydromodule extract (ratio of solution mass to dry weight of raw material) ( $\xi$ ), temperature $\left(t,{ }^{\circ} \mathrm{C}\right)$, extraction time $\left(\tau\right.$, s.). The solvents used were $\mathrm{C}_{2} \mathrm{H}_{5} \mathrm{OH}$ alcoholandhexane $\mathrm{C}_{6} \mathrm{H}_{14}$.

In experimental studies, control instrumentation, equipment and experimental microwave exposure stands were used, among which the authors' developments [10;11]. In the laboratory installation, the power of the microwave intensifier can be varied from 0.4 to $1.6 \mathrm{~kW}$, the volume of the solvent is from 0.008 to $0.015 \mathrm{~m}^{3}$, the mass of the canola seeds and soybean seeds is from 2 to 5 $\mathrm{kg}$. The frequency of microwaves is $2450 \mathrm{MHz}$.

In order to study the kinetics of the extraction process, the solution concentration was determined. The extraction of oil from the micelle to determine the concentrations was carried out arbitrarily by evaporating the solvent. To obtain a comparative study of the kinetics of oil extraction from the canola seeds, the studies were carried out in two stages, using the usual conventional method(in thermostat TS-80)and applying microwave radiation.

In a conventional method, a container with crushed rape cake (or grains) and solvents were placed in the thermostat. The thermoregulator of the thermostat maintained the temperature inside the vessels at the same level during the extraction process. To study the oil concentration, samples were taken every 10 minutes. They were weighed and placed in the SPT-200 desiccator, where evaporation of the solvent from the test sample took place, and then weighed on the analytical balance VLA-200G-M.

The main elements of the experimental microwave stand (Figure 1) were a chamber in which, due to the magnetron, a microwave field was created, and a vessel in which the extraction process itself proceeded. The stand ensured power control of the microwave field. The operating principle of the experimental stand is as follows: in the vessel with product 3 , an extraction process takes place under the action of the microwave field in the chamber 1.The extractant vapour enters the reflux condenser 2 , condenses and drains back into the reaction vessel together with the sample studied and the solvent under study. Using the syringe 5 the micelle is collected for further investigation.

To be sure about the reliability of the results, the experiments were carried out in 6-fold replication and, in the case of significant scattering of the results, (with a variation coefficient of more than $15 \%$ ), the number of replicates increased to 10 . Analytical studies were made using software packages for the PC: MathCAD, Excel. 


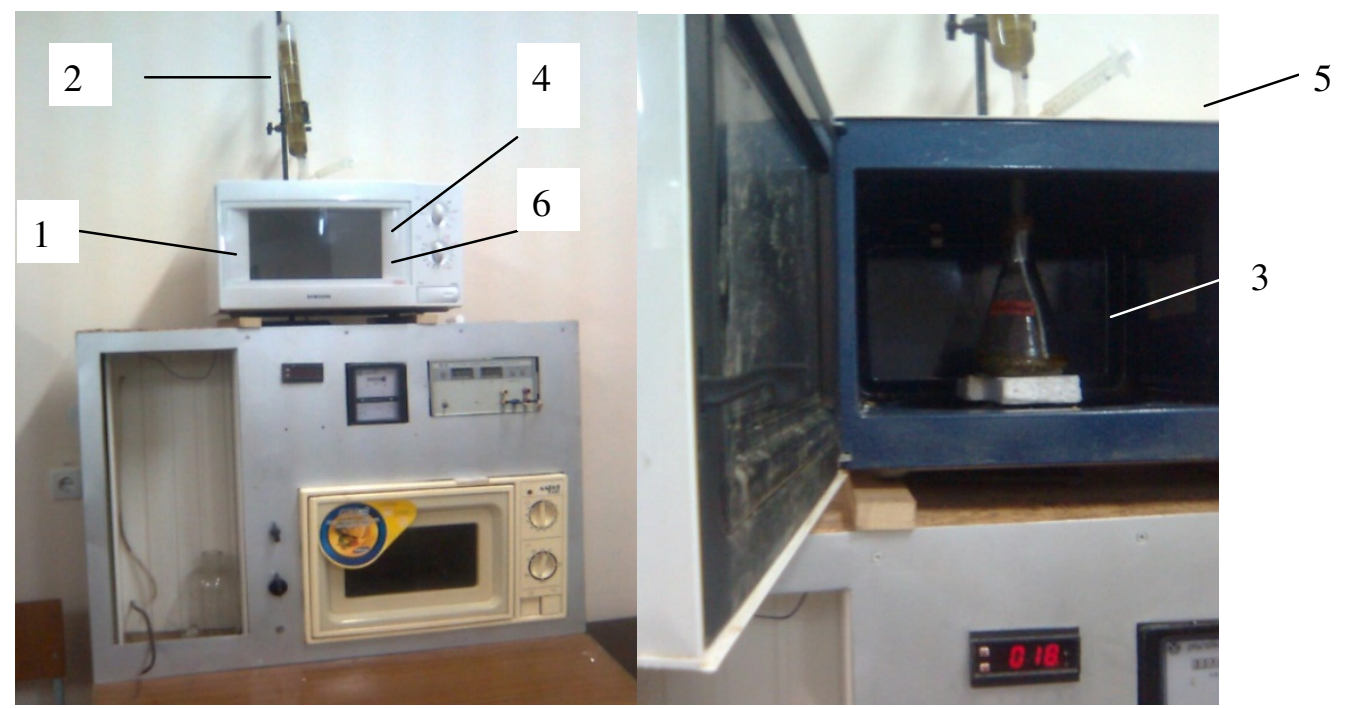

Fig. 1. Stand for oil extraction: 1 - high-frequency microwave camera; 2 - reverse water cooler; 3 - chamber with the product; 4 -power control; 5 - syringe for taking samples; 6 - timer

\section{Results and discussion}

In these studies, the influence of the main input parameters, indicated in the "legend" under the graphs, was studied.According to some authors [2;4], other parameters have no significant effect and were not considered in this paper. The coefficient of variation in experiments did not exceed $9.8 \%$.

The kinetics of extraction of the canola oil by solvents hexane and alcohol under different temperature regimes is reflected in Figs. 2, 3.With increasing temperature, the rate of oil extraction increased. This is due to the increase in the rates of chemical reactions and diffusion coefficients, at which the driving force of the process increases and the resistance to its flow decreases.

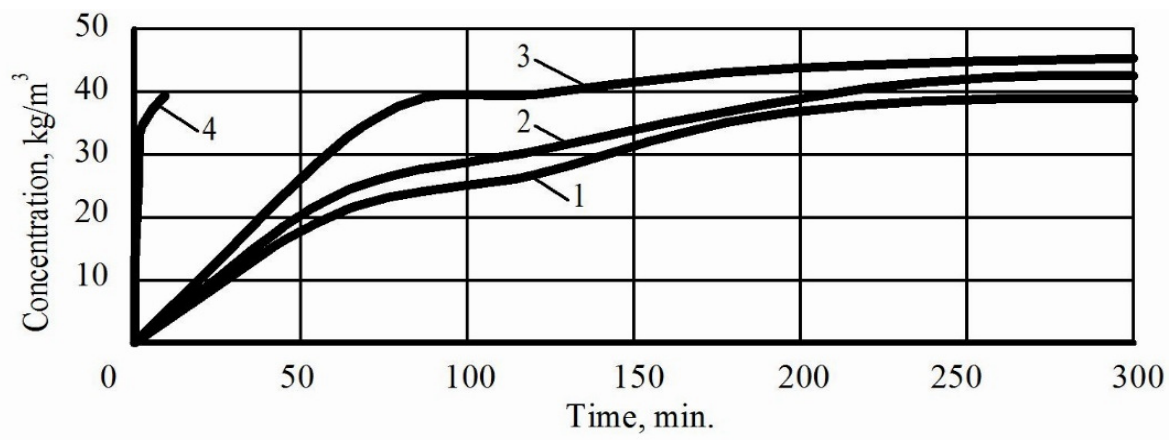

Fig. 2. Dependence of concentration on time in the process of extracting canola seed meal with hexane (colza + hexane, oilcake $2-4 \mathrm{~mm}, 1: 3$, no MW) at different temperatures: $1-5 \mathrm{~h}, 30^{\circ} \mathrm{C} ; 2-5 \mathrm{~h}, 40{ }^{\circ} \mathrm{C} ; 3-5 \mathrm{~h}, 50{ }^{\circ} \mathrm{C} ; 4-10 \mathrm{~min}, 68.8^{\circ} \mathrm{C}$

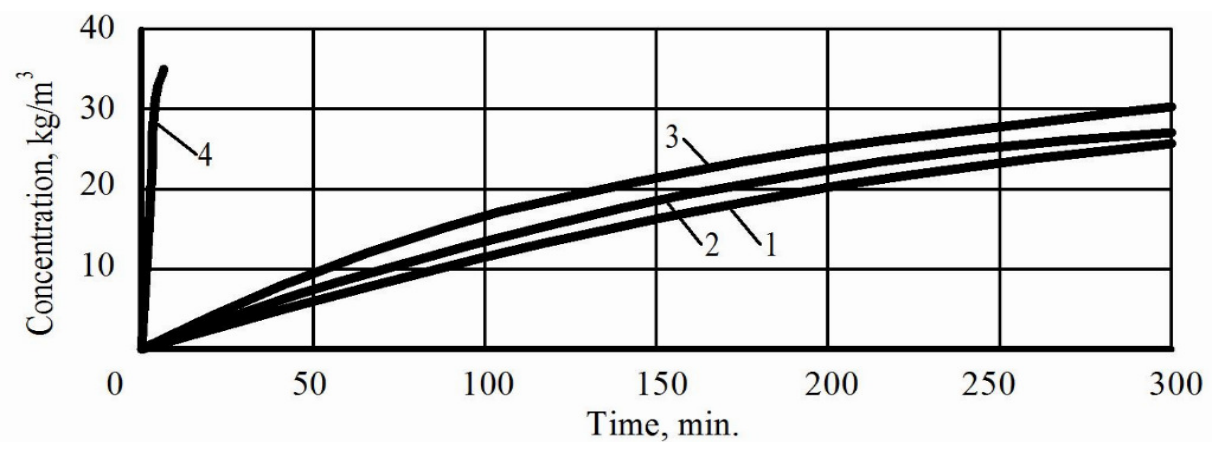

Fig. 3. Dependence of concentration on time in the process of extraction of oilcake by alcohol (colza + alcohol, oilcake 2-4 mm, 1: 3, no MW) at different temperatures: $1-30{ }^{\circ} \mathrm{C} ; 2-40{ }^{\circ} \mathrm{C} ; 3-50{ }^{\circ} \mathrm{C} ; 4-10 \min , 78.3^{\circ} \mathrm{C}$ 
The results of studies of the kinetics of oil extraction from canola for various hydromodules (the ratio of the solid and liquid phases) are shown in Fig. 4, 5 (when extracting the canola meal in an electromagnetic field with various solvents). The value of the hydromodule 1: 3 provides the highest concentration of oil (approximately 2.3 times higher than the hydromodule 1: 10).

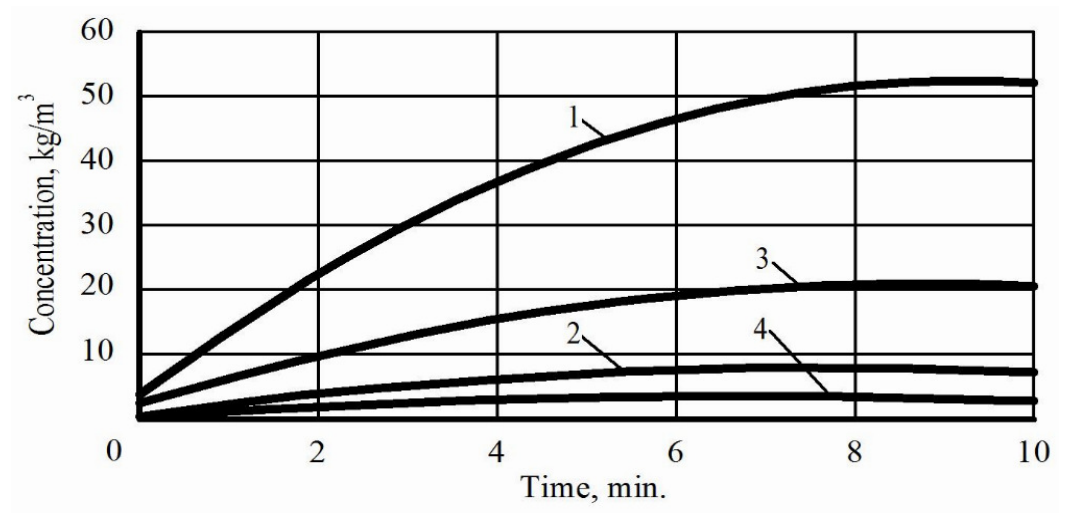

Fig. 4. Dependence of concentration on time in the process of extracting canola meal with hexane (colza + hexane, oilcake 2-4 mm, $10 \mathrm{~min}, \mathrm{MW}$ ) at various ratios of solid and liquid phases: $1-1: 3 ; 2-1: 20 ; 3-1: 10 ; 4-1: 5$.

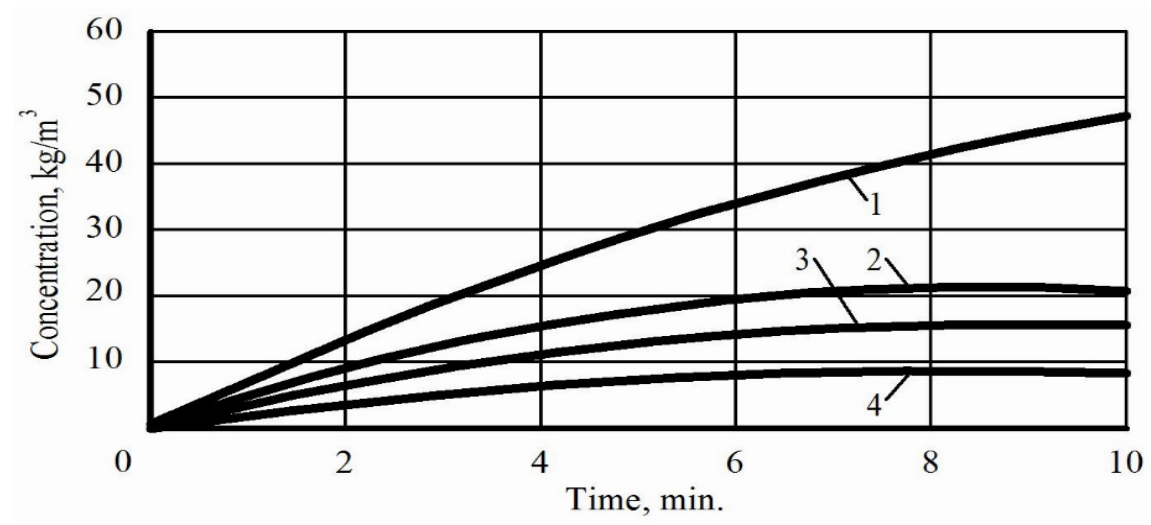

Fig. 5. Dependence of concentration on time in the process of extraction of oilseed meal with alcohol (colza + alcohol, oilcake $2-4 \mathrm{~mm}, \mathrm{MW}, 10 \mathrm{~min}, \mathbf{7 8 . 3}^{\circ} \mathrm{C}$ ) for various ratios of solid and liquid phases: $1-1: 3 ; 2-1: 5 ; 3-1: 10 ; 4-1: 20$

The dependencies shown in Fig. 6, 7 indicate the effect of the solvent on the extraction process.

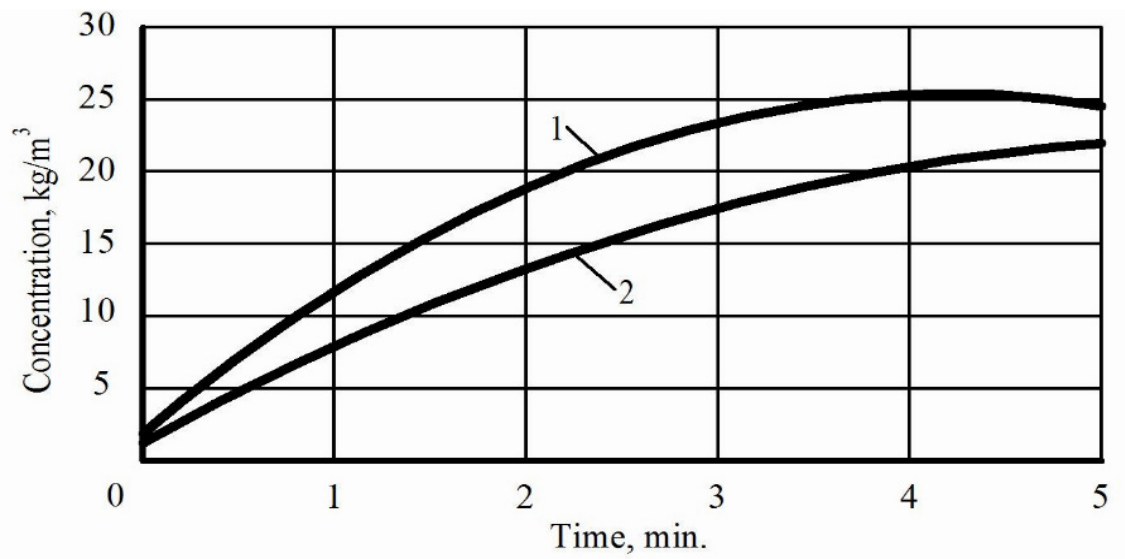

Fig. 6. Influence of the solvent in the process of extraction of crushed grain of canola seeds with hexane and alcohol (corn 0.5-1 mm, 1: 3, no MW, $5 \mathrm{~min}$ ) without the influence of the MB field: $1-$ colza + hexane, $68.7^{\circ} \mathrm{C} ; 2-$ colza + alcohol, $78.3^{\circ} \mathrm{C}$ 


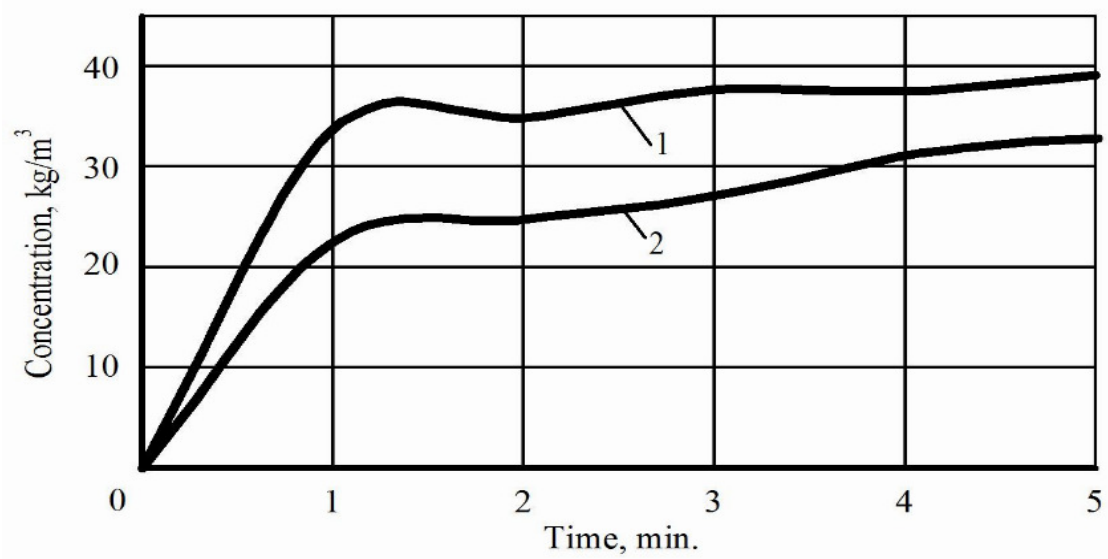

Fig. 7. Effect of solvent during extraction of crushed canola seed meal with hexane and alcohol (oilcake 2-4 mm, 1: 3, no MW) without the influence of the MB field:

1 - colza + hexane, $5 \mathrm{~min}, 68.7^{\circ} \mathrm{C} ; 2-$ colza + alcohol, $5 \min , 78.3^{\circ} \mathrm{C}$

Comparison of the concentration of the extracted oil shows that the hexane solvent provides higher process intensity than alcohol. However, when studying the intensity of the action of solvents under the influence of the MKV field (Figures 8,9), it was found that the intensifying effect of ethyl alcohol during extracting in the MKV field is 1.5 times greater than in hexane. This is explained by the polarity of ethyl alcohol as opposed to the non-polarity of hexane.

This allows us making a conclusion that for use in the extraction of oil from the canola seeds in a microwave environment it is necessary to give preference to a polar, non-toxic, safer solvent (as compared to hexane) ethyl alcohol.

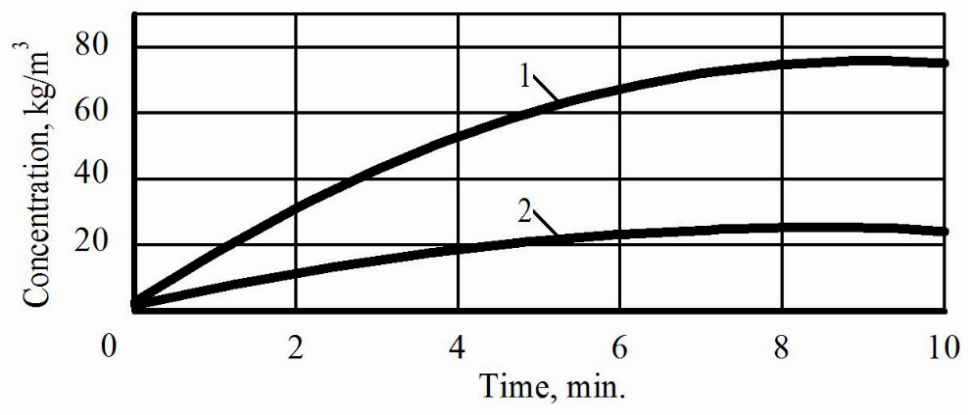

Fig. 8. Influence of the power of the microwave field in the process of extracting canola seeds (colza + hexane, corn $0.5-1 \mathrm{~mm}, 1: 3,10 \mathrm{~min}, 68.7^{\circ} \mathrm{C}$ ) with hexane: 1 - MW; 2 - no MW, $10 \mathrm{~min}, 68.7^{\circ} \mathrm{C}$

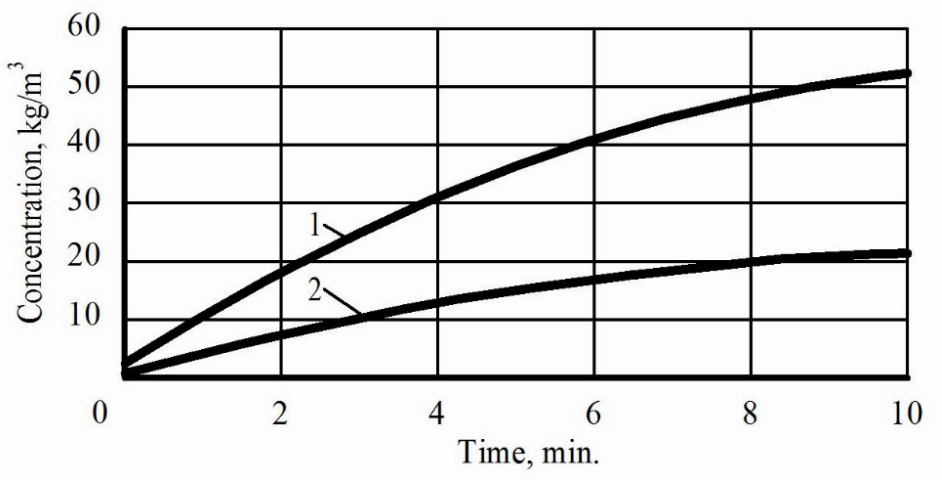

Fig. 9. Influence of the power of the microwave field in the process of extracting canola (colza + alcohol, corn 0.5-1 mm, 1: 3, $10 \mathrm{~min}, \mathbf{7 8 . 3}^{\circ} \mathrm{C}$ ) with alcohol: 1 - MW; 2 -no MW.

Thus, when comparing the concentration of the oil obtained as a result of extracting the crushed canola seeds using a microwave field, and also intensifying the process by boiling under normal 
conditions, the output of the target component increased by an average of 3-4 times. Intensification of the extraction process by the microwave field is more effective than the boiling method by the classical method. This is due to the effect of barodiffusion. Intensification of the extraction process by the microwave field occurs by increasing pressure inside the capillaries of plant raw materials, followed by their destruction and maximum arrival of the target component into the extractant. A barodiffusion flux arises that contributes to a significant reduction in the extraction process time and a considerable increase in the extraction of valuable components from the raw material.

Influence of the microwave field on the extraction process. In Fig. 10, 11, under constant conditions of change, the power of the microwave field is: $127 \mathrm{~W}, 255 \mathrm{~W}, 425 \mathrm{~W}$. Increasing the power of the microwave field in the range from 127 to $425 \mathrm{~W}$ provides an increase in the oil concentration by $23-28 \%$.

When the oilcake was extracted from the investigated oily crops, intensification of the microwave field reached up to 2 times; this is explained by a violation of the cell integrity of the cake after passing through the technological scheme of pressing, and, accordingly, a significant facilitation of the further process of extraction of the oil by the solvent. Therefore, intensification of the extraction process by boiling without an MW field is also effective for this case. With the use of microwave technologies for extraction of plant raw materials, less time is required for the oil extraction, and at the same time the yield and quality of the product obtained increases with less consumption of energy.

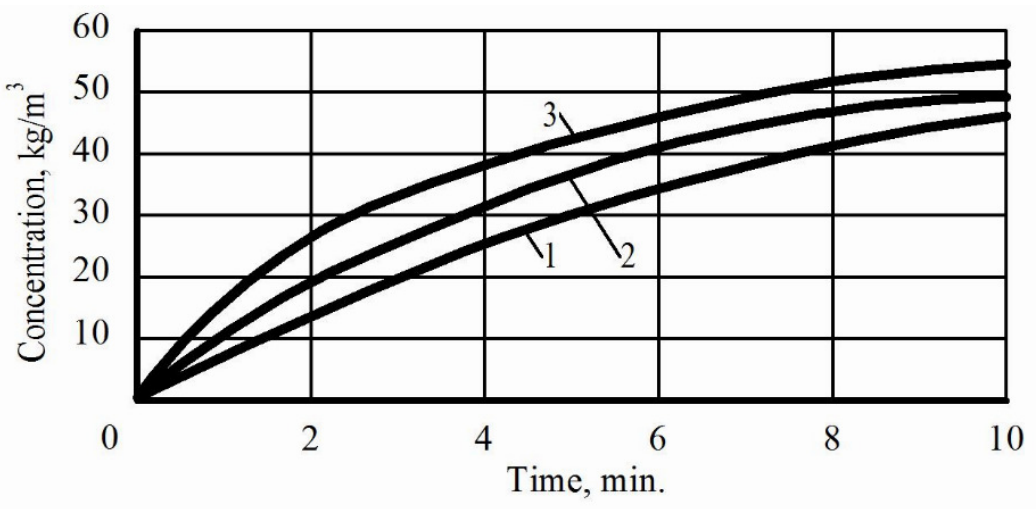

Fig. 10. Influence of the power of the microwave field during extraction of oil from canola meal (colza + hexane, oilcake 2-4 mm, 1: 3, MW, $10 \mathrm{~min}, 68.7^{\circ} \mathrm{C}$ ) with hexane: $1-127 \mathrm{~W} ; 2-255 \mathrm{~W} ; 3-425 \mathrm{~W}$

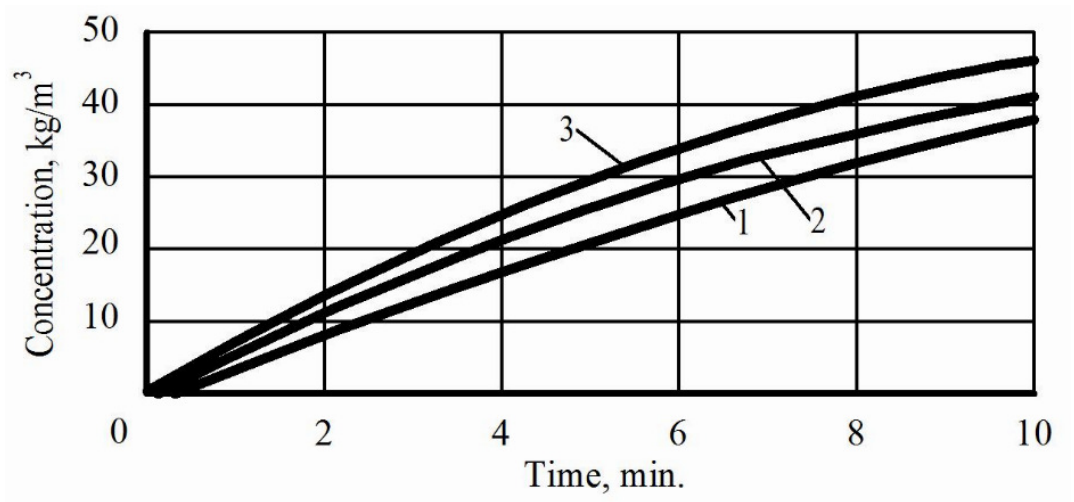

Fig. 11 Influence of the power of the microwave field in the process of extracting oil from canola meal (colza + alcohol, oilcake 2-4 mm, 1: 3, MW, $10 \mathrm{~min}, 78.3^{\circ} \mathrm{C}$ ) with alcohol:

$$
1-127 \mathrm{~W} ; 2-255 \mathrm{~W} ; 3-425 \mathrm{~W}
$$

\section{Conclusions}

The kinetics of oil extraction from canola depends on the size of the raw material fractions, the action of the pulsed electromagnetic field, the extract hydromodule, temperature, the extraction time, the kind of solvent. Studies have shown that, in contrast to the classical method, extraction in the 
electromagnetic field increases the oil yield by an average of 2 times; it increases the concentration index, and also reduces the oil extraction time to $97 \%$.

\section{References}

1. Loganes C., Ballali S., Minto C. Main properties of canola oil components: A descriptive review of current knowledge. Open Agriculture Journal, Vol.10, 2016, pp.69-74.

2. Thiyam-Holländer U., Eskin M., Matthäus B. Canola and Rapeseed: Production, Processing, Food Quality and Nutrition, Boca Raton, Retrieved, 2015, 40 p.

3. Robertson D. Structure and functions of the cell. 1980. $159 \mathrm{p}$.

4. Аксельруд Г., Лысянский В. Экстрагирование. Система твердое тело-жидкость(Еxtraction. A solid-liquid system), 1974, Ленинград. 256 p. (In Russian).

5. Белобородов В., Забровский Г., Вороненке Б. Процессы массо- и теплопереноса масложирового производства (Processes of mass and heat transfer in fat and oil production), Санкт-Петербург: ВНИИЖ, 2000. 430 p. (In Russian).

6. Rekas A., Scibisz I., Siger A., Wroniak M. The effect of microwave pretreatment of seeds on the stability and degradation kinetics of phenolic compounds in rapeseed oil during long-term storage. Food Chemistry, Vol.222, 2017, pp.43-52.

7. Burdo O. Food nanotechnologies, Herson, 2013, 294 p.

8. Бурдо О.Г. Технологии направленного энергетического действия в АПК (Technologies of directed energy action in an agroindustrial complex). Научные труды Одесской национальной академии пищевых технологий. 2015, Вып. 47, Том 1. Одесса. pp. 4-10. (In Ukrainian).

9. Burdo, O., Terziev, S., Bandura V., Jaravoj I. The mechanodiffusion effect - a new phenomenon in heat and mass transfer, Materials of the XV Minsk International Forum on Heat and Mass Transfer), 23-26 May 2016, Vol.2., Minsk, pp. 224-228.

10. Bandura V., Koljanovska L., Ruzhicka N. Intensification of extraction in the technology of the canola oil production. Vibrations in engineering and technologies, 2011, Vol. 61(1), pp. 98-102.

11. Бандура В., Коляновская Л. Разработка технологической схемы извлечения масла при помощи микроволнового интенсификатора (Development of a technological scheme for extracting oil by means of a microwave intensifier). Научные труды Одесской национальной академии пищевых технологий. 2014, Вып. 45, Том 3, Одесса. pp. 39-42. (In Ukrainian). 